\title{
Identifikasi Morfologi dan Uji Aktivitas Antimikroba Terhadap Bakteri Escherichia coli Dari Fermentasi Buah Markisa (Passiflora sp.)
}

\author{
Habibi Hidayat \\ Program Studi Kimia FMIPA Universitas Islam Indonesia \\ Jalan Kaliurang KM 14,5, Sleman, Yogyakarta, 55584 \\ E-mail: habibihidayat13@gmail.com
}

\begin{abstract}
ABSTRAK
Telah dilakukan studi identifikasi bakteri dari buah Markisa dan uji aktivitas antimikroba terhadap bakteri Escerichia coli. Sampel yang digunakan dalam penelitian ini berasal dari buah Markisa, dimana penelitian ini bertujuan untuk mengidentifikasi morfologi bakteri yang tumbuh dalam proses fermentasi buah markisasecara mikroskopik, dan uji aktivitas antimikroba dari hasil fermentasi Markisa (Passiflora Sp.) terhadap bakteri Escerichia coli. Identifikasi morfologi yang dilakukan dengan metode pewarnaan Gram dan uji aktivitas antimikroba dengan menggunakan metode cakram. Hasil yang diperoleh dari terhadap kedua isolat yaitu S1 berbentuk basil dan S2 berbentuk basil dan kokus. Perhitungan jumlah koloni pada pengenceran $10^{-7}$ diperoleh S1 sebanyak $16.10^{7} \mathrm{cfu} / \mathrm{ml}$ dan S2 sebanyak $30.10^{7} \mathrm{cfu} / \mathrm{ml}$. Uji aktivitas antimikroba terhadap bakteri patogen Escerichia coli selama 1 x 72 jam yaitu isolat S1 diperoleh zona hambat pertumbuhan bakteri sebesar $11 \mathrm{~mm}, 13 \mathrm{~mm}$ dan $15 \mathrm{~mm}$ dan isolat $\mathrm{S} 2$ sebesar $13 \mathrm{~mm}, 14 \mathrm{~mm}$ dan $16 \mathrm{~mm}$.
\end{abstract}

Kata kunci: Markisa, Escerichia coli, Antimikroba, Pewarnaan Gram

\begin{abstract}
Study of morphological identification and testing of antimicrobial activity for passionfruit isolates have been done againstEscerichia coli. Examined Samples were taken from passionfruit, where This study aims to find out morphology identification of the isolates microscopically and antimicrobial activity of Passionfruit (Passiflora sp.) fermentation against Escerichia coli bacteria. The identification of morphology was conducted using Gram staining method while testing of antimicrobial activity was performed using cakram method. Obtained results from the two isolates showed that the shape of S1 was basil and the shape of S2 was basil and coccus. Collony calculation in the $10^{-7}$ dilution exhibited the number of $\mathrm{S} 1$ was $16.10^{7} \mathrm{cfu} / \mathrm{ml}$ and $\mathrm{S} 2$ was $30.10^{7}$ $\mathrm{cfu} / \mathrm{ml}$. Testing of antimicrobial activity against pathogenic bacteria Escherichia coli at $1 \mathrm{x} 72$ hours of S1 isolate gave inhibition zones for bacterial growth of $11 \mathrm{~mm}, 13 \mathrm{~mm}$ and $15 \mathrm{~mm}$. At the same, S2 isolate gave inhibition zones of $13 \mathrm{~mm}, 14 \mathrm{~mm}$ and $16 \mathrm{~mm}$.
\end{abstract}

Key words: Passionfruit, Escerichia coli, antimicrobial, Gram Staining

Pendahuluan

Markisa merupakan salah satu jenis

buah yang terdapat di Indonesia. Buah ini berasal dari negara Brasil, dan

berkembang pesat di beberapa daerah di Indonesia seperti di Sumatera Utara,

Identifikasi Morfologi dan Uji Aktivitas Antimikroba Terhadap Bakteri Escherichia coli Dari Fermentasi

Buah Markisa (Passiflora sp.)

(Habibi Hidayat) 
Sumatera Barat, Lampung, dan Sulawesi

Selatan. Selain itu, Markisa juga dapat diperoleh dengan mudah di daerah Yogyakarta. Buah Markisa memiliki banyak manfaat bagi kesehatan karena memiliki kandungan nutrisi yang berkhasiat. Buah Markisa identik mempunyai rasa masam sehingga jarang dimanfaatkan secara langsung dan hanya dibuat sebagai bahan minuman (Overlando, dkk., 2013). Markisa merupakan sumber serat untuk membersihkan dinding usus, meningkatkan pencernaan, dan membantu mencegah serangan jantung dan stroke.

Biasanya suatu mikroba hanya dapat menimbulkan penyakit jika berhasil masuk ke dalam tubuh melalui saluran tertentu, misalnya dengan melalui saluran pencernaan. Mikroba yang dapat menginfeksi dan menimbulkan penyakit adalah mikroorganisme yang mempunyai daya patogenitas yang tinggi, daya virulensi yang kuat, daya invasi yang tinggi sehingga dapat berkembang biak dan menyebar ke dalam tubuh inang yang peka, serta mempunyai daya pertahanan dan daya hindar yang baik terhadap serangan sel-sel fagosit di dalam tubuh inang.Menurut Tagg, bakteri gram positif bersifat bakterisida tidak hanya membunuh bakteri, bukan hanya menghambat, sebagai akibat lemahnya proton motive force dan hilangnya kemampuan potensi membran dalam mencegah pertumbuhan bakteri sejenis dan mempunyai tempat pelekatan yang spesifik bagi bakteri patogen(Hidayat, 2011).

Fermentasi adalah reaksi dengan menggunakan biokatalis untuk mengubah bahan baku menjadi produk. Biokatalis yang digunakan adalah bakteri,yeastatau jamur (Overlando, dkk., 2013). Secara umum, makanan fermentasi lebih awet dari bentuk segarnya karena kondisi asam tidak disukai oleh bakteri kontaminan. Disamping itu, makanan fermentasi cita rasanya lebih enak dibanding bentuk segarnya, dan nilai gizinya lebih tinggi, umumnya lebih mudah dicerna karena telah mengalami penguraian selama proses fermentasi dan terbentuk molekulmolekul yang lebih sederhana dan lebih mudah dicerna (Surono, 2004). Menurut Ovelando, dkk., (2013), beberapa langkah utama yang diperlukan dalam melakukan proses fermentasi, yaitu :

a. Seleksi mikroba atau enzim yang sesuai dengan tujuan.

b. Seleksi media sesuai dengan tujuan.

c. Sterilisasi semua bagian penting untuk mencegah kontaminasi. 
d. Pengecekan semua perlengkapan terutama pada bagian pengendalian proses.

e. Evaluasi hasil maupun proses secara menyeluruh.

Melihat kandungan dan manfaat yang terdapat di dalam buah markisa, Selain dibuat minuman, apakah markisa juga dapat digunakan sebagai antimikroba maka dilakukan identifikasi morfologi dan uji aktivitas terhadap bakteri Eschericia colidari hasil fermentasi buah Markisa. Pada penelitian sebelumnya banyak yang melakukan uji aktivitas dengan menggunakan sampel yang berbeda. Sehingga peneliti tertarik untuk melakukan penelitian terhadap buah markisa.

\section{Tujuan Penelitian}

Tujuan penelitian ini adalah sebagai berikut:

1. Untuk mengetahui identifikasi morfologi secara mikroskopik dari bakteri hasil fermentasi Markisa (Passiflora Sp.).

2. Untuk mengetahui aktivitas antimikroba dari fermentasi Markisa (Passiflora Sp.) terhadap bakteri Escheria coli.

\section{Metode Penelitian}

Penelitian ini membutuhkan bahanbahan seperti: buah Markisa kuning, alkohol 70\%, indikator kertas $\mathrm{pH}$ universal, nutrient agar, nutrient broth, pepton water, kristal violet, larutan lugol, aseton alkohol, safranin, Mueller hilton, antibiotik (eritrombisin, ampicilin), akuades, kertas saring, kapas, Euschericia coli, kertas aluminium foil, kertas wrap

Alat-alat yang digunakan yakni autoclave, rak tabung reaksi, petridish, jarum ose, pembakar bunsen, erlemenyer, pipet mikro, mikroskop, kaca objek, stopwatch, vortex, microtube, inkubator.

\section{Prosedur Kerja}

\section{A. Fermentasi Buah Markisa}

Proses fermentasi Markisa Kuning dilakukan dengan mengambil satu atau dua buah Markisa yang sudah matang kemudian di kupas dan letakkan ke dalam daun pisang yang telah di bersihkan dengan alkohol dan dipanaskan lalu ditutup rapat-rapat, kemudian dimasukkan ke dalam tupper wearyang telah di lubangi dan di diamkan selama 36 jam dan 48 jam pada suhu kamar.

\section{B. Isolasi dan identifikasi Morfologi Bakteri}

Hasil Fermentasi 36 jam dan 48 jam di ambil dan dilakukan proses isolasi. Isolasi dilakukan dengan cara 
pengenceran. Dimana dalam proses pengenceran tersebut sebanyak 1 gram daging buah markisa hasil fermentasi dimasukkan ke dalam tabung reaksi yang berisi 9 mlnutrient brothcair. Perlakuan ini dilakukan sama untuk masing-masing sampel yang 36 jam dan 48 jam. Selanjutnya diinkubasi pada suhu $37^{\circ} \mathrm{C}$ selama 24 jam.

Setelah diinkubasi dilakukan pengenceran bertingkat. Dengan menggunakanpepton water. Sebanyak 0,9 $\mathrm{ml}$ pepton water masing-masing dimasukkan ke dalam 7 buah microtube, selanjutnya satu buah microtube tersebut ditambahkan dengan $0,1 \mathrm{ml}$ hasil fermentasi. Kemudian microtube tersebut di vortex selama 30 detik lalu di ambil 0,1 $\mathrm{ml}$ dan dimasukkan ke dalammicrotube berikutnya. Perlakuan ini terus dilakukan sampaimicrotube terakhir. Setelah itu microtubeyang terakhir (ke 7) diambil 0,1 $\mathrm{ml}$ dan dilakukan penanaman pada media padat. Media padat yang dibuat dari2 gram nutrient agar dengan 0,8 gramnutrient brothdalam $100 \mathrm{ml}$ akuades. Selanjutnya diratakan dengan menggunakandirglassky, dan diinkubasi pada suhu $37^{\circ} \mathrm{C}$ selama 24 jam.

Selanjutnya dilakukan penanaman menggunakan metode streak zigzag dengan mengambil 1 ose hasil inkubasi ditanam pada media padat yang baru dan diinkubasi pada suhu $37^{\circ} \mathrm{C}$ selama 24 jam.

\section{Identifikasi Morfologi Bakteri}

Dari media padat yang telah diinkubasi tadi diambil 1 ose bakteri lalu diletakkan di atas kaca objek, dilebarkan dan dilakukan fiksasi bakterinya. Selanjutnya dituangkan kristal violet sebanyak 3-5 tetes selama 5 menit. Lalu dicuci dengan air mengalir, ditambahkan lugol dan diamkan selama 45-60 detik kemudian cuci lagi dengan air mengalir. Selanjutnya celupkan dalam bejana yang berisi aseton alkohol sambil digoyanggoyangkan selama 30 detik. Kemudian dicuci lagi dengan air yang mengalir, kemudian warnai dengan safranin sebanyak 2-3 tetes selama 1-2 menit, dan dicuci dengan air yang mengalir lalu dikeringkan. Kemudian lihat bentuk morfologi bakteri dengan menggunakan mikroskop perbesaran $40 \mathrm{X}$.

\section{Uji Aktivitas Antimikroba}

Uji aktivitas antimikroba dilakukan dengan cara melakukan kultur bakteri menggunakan media cair nutrient broth. Sebanyak 1 ose bakteri dari media padat di kultur didalam media cair selama 24 jam pada suhu $37^{\circ} \mathrm{C}$. Di siapkan juga 1 $\mathrm{ml}$ bakteri patogen Escherichia coliyang Identifikasi Morfologi dan Uji Aktivitas Antimikroba Terhadap Bakteri Escherichia coli Dari Fermentasi Buah Markisa (Passiflora sp.) 
dikultur di dalam media cair nutrient broth, dan diinkubasipada suhu $37^{\circ} \mathrm{C}$ selama 24 jam. Selanjutnya dilakukan proses persiapan media Mueller hilton $(\mathrm{MH})$, diambil 2,28 gram $\mathrm{MH}$ ditambahkan 1,2 gram nutrient agar dan dilarutkan dengan akuades sebanyak 60 ml. Dalam proses uji aktivitas antimikroba ini digunakan antibiotik sebagai standar yaituEritrombisin (E) dan Ampicillin (amp).

\section{Pembahasan}

\section{A. Fermentasi Buah Markisa}

Proses fermentasi dilakukan dari sampel buah markisa yang diperoleh di kota Yogyakarta. Dalam proses fermentasi dilakukan sterilisasi alat yang akan digunakan agar tidak terjadi kontaminan terhadap bakteri. Adapun nilai $\mathrm{pH}$ yang diperoleh untuk masingmasing proses fermentasi dari 36 jam sebesar 3 dan untuk yang 48 jam sebesar 4 (Gambar 1). Pada awalnya PH sampel hasil sebesar 5. Penurunan $\mathrm{pH}$ dari masing-masing sampel selama proses fermentasi, disebabkan karena pada saat proses fermentasi terbentuk asam laktat, aroma, dan flavour yang dihasilkan dari kandungan buah markisa. Selain itu, menurut Surono (2004) dalam proses fermentasi mikroba akan menghasilkan senyawa $\mathrm{CO}_{2}$, asam asetat, etanol, manitol, dan senyawa flavour dari heksosa.

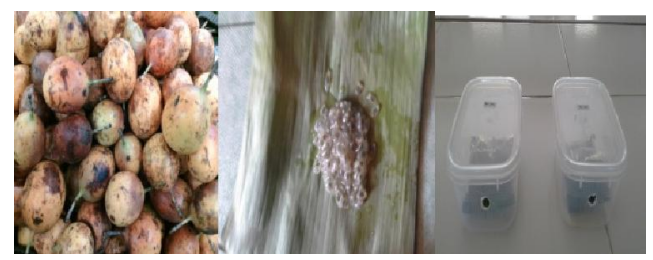

(a) (b)

(c)

Gambar 1. Fermentasi Buah Markisa: (a) Buah Markisa; (b) Daging Buah Markisa (c) Proses Fermentasi

\section{B. Isolasi dan identifikasi Morfologi Dari Bakteri}

Isolasi bakteri ini dilakukan bertujuan untuk memisahkan dan membiakkan bakteri yang terdapat di dalam campuran dengan menggunakan media kultur sehingga diperoleh isolat bakteri atau biakkan murni dari bakteri tersebut (Darwis dan Sukar, 1999). Pada proses isolasi ini media isolasi spesifik yang digunakan adalah media selektif yaitu nutrient brothataude Mann Rogosa Sharpe Broth. Bentuk medianya seperti bubuk bewarna kuning pucat. Media selektif ini digunakan untuk menumbuhkan dan memelihara bakteri tertentu, dengan sifat kekhususannya tersebut, maka media ini akan menyeleksi bakteri yang ingin ditumbuhkan yaitu Bakteri Asam Laktat (BAL). 
Bakteri dalam sampel diisolasi dengan menggunakan metode pengenceran bertingkat danstreak pada MRS agar. Kemudian dilakukan inkubasi pada suhu $37^{\circ} \mathrm{C}$ selama 2 hari. Proses pengenceran bertingkat dilakukan sampai $10^{-7}$ dalam pepton water. Hal ini bertujuan untuk memperkecil atau mengurangi jumlah mikroba yang tersuspensi dalam cairan tersebut. Selanjutnya dilakukan inkubasi selama 1 hari pada suhu $37^{\circ} \mathrm{C}$. Setelah dilakukan proses inkubasi maka didalam petridish yang berisi media padat akan terdapat sejumlah koloni-koloni bakteri. Koloni tunggal dari petirdish tersebut selanjutnya dipindahkan ke dalam petridish lain dengan perlakuan yang sama dengan menggunakan metode streakagar mendapatkan kultur murni dari bakteri. Dari hasil streak tersebut diperoleh 2 isolat bakteri, yaitu S1 dan S2.

Dari hasil perhitungan jumlah koloni pada pengenceran $10^{-7}$ diperoleh $\mathrm{S} 1$ sebanyak $16.10^{7} \mathrm{cfu} / \mathrm{ml}$ dan $\mathrm{S} 2$ sebanyak $30.10^{7} \mathrm{cfu} / \mathrm{ml}$ (Gambar 2). Karena pada pengenceran tersebut koloni-koloni bakteri sudah terpisah dengan baik, jumlah total koloni ini memenuhi kriteria sebagai pangan probiotik. Menurut WHO (World Health
Organization) dalam Dewita (2010) sebagai pangan probiotik yaitu berada pada jumlah $10^{6}-10^{8} \mathrm{cfu} / \mathrm{ml}$.

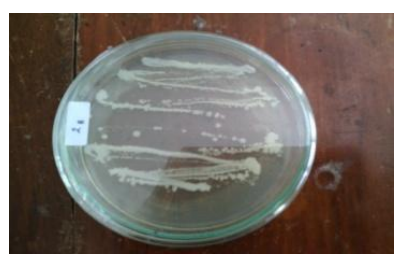

Gambar 2. Penampakan BAL pada Medium MRS agar

\section{Identifikasi Morfologi Bakteri}

Isolat bakteri yang berhasil diisolasi menggunakan media selektif nutrient brothberdasarkan sifat-sifat umumnya adalah Bakteri Asam Laktat (BAL). Bakteri Asam Laktat (BAL) merupakan bakteri yang mampu menghasilkan asam laktat pada media pertumbuhannya. Sifatsifat umum dari BAL antara lain : bentuknya basil (batang), kokus (bulat), sifat gram positif, katalase negatif, endospora negatif, motilitas negatif, dan mampu menghasilkan asam laktat. Identifikasi dilakukan terhadap kedua isolat yaitu $\mathrm{S} 1$ dan $\mathrm{S} 2$.

Identifikasi BAL secara makroskopis yang telah diamati diperoleh bentuk koloni (Tabel 2). Untuk mengetahui jenis bakteri yang dihasilkan maka dilakukan identifikasi secara mikroskopik yaitu dengan pewarnaan gram. Uji gram ini dilakukan untuk Identifikasi Morfologi dan Uji Aktivitas Antimikroba Terhadap Bakteri Escherichia coli Dari Fermentasi Buah Markisa (Passiflora sp.) (Habibi Hidayat) 
menggelompokkan bakteri berdasarkan yang menggunakan larutan pewarna reaksi kimia yang terbagi menjadi dua Gram (Gram Stainning).

yaitu Gram positif dan Gram negatif,

Tabel 2. Hasil Pengamatan Koloni

\begin{tabular}{|c|c|c|c|c|c|c|}
\hline isolat & ukuran & bentuk & elevasi & $\begin{array}{c}\text { bentuk } \\
\text { pinggir }\end{array}$ & warna & uji gram \\
\hline S1 & kecil & $\begin{array}{c}\text { teratur } \\
\text { (sirkular) }\end{array}$ & datar & lobate & $\begin{array}{c}\text { putih } \\
\text { kekuning- } \\
\text { kuningan }\end{array}$ & $\begin{array}{c}\text { basil (gram } \\
\text { positif) }\end{array}$ \\
\hline S2 & Sedang & $\begin{array}{c}\text { Teratur } \\
\text { (sirkular) }\end{array}$ & cembung & $\begin{array}{c}\text { Bulat } \\
\text { penuh }\end{array}$ & Putih & $\begin{array}{c}\text { Basil dan kokus } \\
\text { (gram positif) }\end{array}$ \\
\hline
\end{tabular}

Proses pewarnaan Gram yang telah dilakukan akan menghasilkan bentuk morfologi dari bakteri tersebut (Gambar 3). Menurut prescot et al dalam Hidayat (2011),ketika sel bakteri yang terdapat pada kaca objek ditambahkan dengan pewarna kristal violet yang bewarna ungu, maka sel bakteri akan menyerap pewarna tersebut. Interaksi antara sel bakteri dengan kristal violet akan semakin kuat dengan ditambahkan lugol. Ketika dicuci dengan alkohol, bakteri Gram positif akan tetap mengikat kompleks kristal violet-lugol sehingga menjadi bewarna ungu. Sedangkan bakteri Gram negatif akan kehilangan kompleks kristal violet lugol karena lapisan peptidoglikan pada bakteri Gram negatif lebih tipis sehingga menjadi tidak bewarna. Ketika ditambahkan dengan safranin yang bewarna merah maka Identifikasi Morfologi dan Uji Aktivitas Antimikroba Terhadap Bakteri Escherichia coli Dari Fermentasi Buah Markisa (Passiflora sp.) (Habibi Hidayat) bakteri Gram negatif akan menyerapnya sedangkan bakteri Gram positif tidak akan menyerap pewarna lagi. Dalam proses pewarnaan Gram ini sampel kultur bakteri dari masing-masing isolat yang digunakan adalah sampel kultur bakteri yang masih segar dan muda.

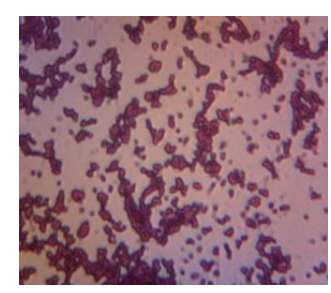

Gambar 3. Bentuk Isolat Bakteri Hasil Pewarnaan Gram

Dari hasil Pewarnaan Gram untuk kedua sampel isolat bakteri semuanya diperoleh bakteri Gram positif, untuk S1 berbentuk basil dan S2 berbentuk basil dan kokus. Pewarnaan Gram pada bakteri ini didasarkan pada tebal atau tipisnya adap Bakteri Escherichia coli Dari Fermentasi 
lapisan peptidoglikan di dinding sel dan banyak sedikitnya lemak pada membran sel bakteri. Bakteri Gram positif memiliki dinding sel yang tebal dan membran sel selapis serta tidak memiliki membran luar. Sedangkan bakteri Gram negatif mempunyai dinding sel tipis yang berada diantara dua lapis membran sel.

\section{Uji Aktivitas Antimikroba}

Uji aktivitas antimikroba dilakukan untuk kedua jenis sampel isolat S1 dan S2 dengan menggunakan metode difusi cakram. Metode difusi cakram merupakan suatu metode yang banyak digunakan dalam proses uji aktivitas antimikroba, metode ini biasa dikenal sebagai metode Kirby-Bauer. Dimana dalam prosesnya sejumlah bakteri uji diinokulasikan pada media agar dan cakram yang mengandung larutan uji. Cakram yang telah mengandung sampel bakteri uji diletakkan pada permukaan media agar yang telah memadat. Dimana sebelumnnya padatan dari media di olesi bakteri patogen Escerichia coli. Kemudian diinkubasi pada suhu $37^{\circ} \mathrm{C}$. Pada 24 jam pertama setelah diinkubasi menunjukkan hasil yang positif pada kedua isolat yaitu dengan adanya zona hambat disekitar cakram sebagai daerah bening yang tidak ditumbuhi bakteri patogen. Menurut Suriawiria dalam
Mardiana (2007) pengukuran kekuatan antibiotik dan antibakteri dengan menggunakan metode Davis Stout dapat dibagi menjadi beberapa kategori (Tabel 2).

Tabel 2.Klasifikasi Respon Zona Hambat

\begin{tabular}{|c|c|}
\hline Diameter Zona Bening & $\begin{array}{c}\text { Respon Hambatan } \\
\text { Pertumbuhan }\end{array}$ \\
\hline$\leq 5 \mathrm{~mm}$ & Lemah \\
\hline $5-10 \mathrm{~mm}$ & Sedang \\
\hline $10-20 \mathrm{~mm}$ & Kuat \\
\hline$\geq 20 \mathrm{~mm}$ & Sangat Kuat \\
\hline
\end{tabular}

Dari hasil uji aktivitas antimikroba yang telah dilakukan terhadap kedua isolat. Daerah hambat yang terbentuk terlihat sebagai daerah terang atau bening disekeliling sumur yang kemudian diukur besarnya dengan menggunakan penggaris. Adapun hasil pengamatan zona bening dapat dilihat dari grafik dibawah ini.

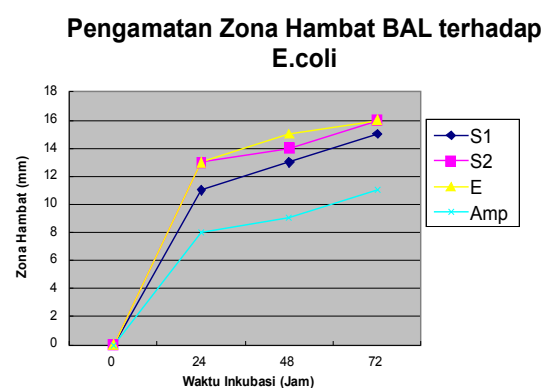

Dari grafik diatas dapat dilihat bahwa kemampuan isolat S1 dan S2 Identifikasi Morfologi dan Uji Aktivitas Antimikroba Terhadap Bakteri Escherichia coli Dari Fermentasi Buah Markisa (Passiflora sp.) (Habibi Hidayat) 
dalam menghambat pertumbuhan bakteri patogen Escerichia coli berbeda-beda. Dimana dari isolat S1 diperoleh zona hambat pertumbuhan bakteri sebesar 11 $\mathrm{mm}, 13 \mathrm{~mm}$ dan $15 \mathrm{~mm}$ (Gambar 4). hasil yang diperoleh untuk isolat S1 ini masuk kedalam kategori respon hambat pertumbuhan bakteri Escerichia coli yang kuat, sedangkan pada isolat S2 memiliki zona hambat terbesar dalam menghambat pertumbuhan bakteri patogen Escerichia coli pada setiap pengamatan 24 jam selama 3 hari yaitu sebesar $13 \mathrm{~mm}, 14$ $\mathrm{mm}$ dan $16 \mathrm{~mm}$. Respon zona hambat untuk isolat S2 ini juga masuk kedalam kategori respon hambat pertumbuhan bakteri Escerichia coli yang kuat. Akan tetapi sampel S2 memiliki zona hambat yang lebih baik daripada sampel S1.

Dalam proses uji aktivitas antimikroba ini juga digunakan dua buah antibiotik standar yaitu eritrombisin dan ampisilin. Dari grafik diatas terlihat bahwa kemampuan tertinggi dari kedua antibiotik dalam menghambat pertumbuhan Escherichia coli adalah antibiotik eritrombisin yaitu sebesar 13 $\mathrm{mm}, 15 \mathrm{~mm}$, dan $16 \mathrm{~mm}$. Pada setiap jam eritrombisin memiliki kestabilan dalam melawan Escerichia coli, dan merupakan antibiotik yang lebih baik dari pada ampisilin karena hasil pengamatan zona hambat dari ampisilin lebih kecil bila dibandingkan dengan kedua isolat dan antibiotik E, yaitu sebesar $8 \mathrm{~mm}, 9 \mathrm{~mm}$, dan $11 \mathrm{~mm}$.

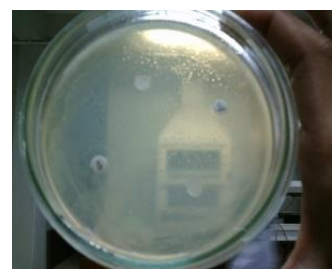

Gambar 4. Uji Aktivitas Antimikroba

Sehingga dapat dilihat bahwa semua isolat masih efektif dan baik dalam menghambat pertumbuhan Escerichia coli selama 72 jam. Oleh sebab itu, jika diaplikasikan sebagai obat antibiotik alami maka dapat dilakukan 1x 48 jam agar efektif dalam menghambat pertumbuhan bakteri Escherichia coli.

\section{Kesimpulan}

Hasil penelitian memberikan kesimpulan:

1. Isolat S1 dan S2 yang diperoleh dari fermentasi buah Markisa adalah uji gram positif yang berbentuk basil dan basil kokus.

2. Uji aktivitas antimikroba untuk masing-masing isolat diperoleh nilai yang bervariasi selama tiga hari, yaitu untuk S1 sebesar $11 \mathrm{~mm}, 13 \mathrm{~mm}$, dan 
$15 \mathrm{~mm}$. Sedangkan S2 sebesar $13 \mathrm{~mm}$, $14 \mathrm{~mm}$, dan $16 \mathrm{~mm}$.

\section{Pustaka}

Darwis dan $\quad 1999$. IsolasiPurifikasi dan Karakterisasi Enzim. Bogor : IPB

Dewita, Sri M. 2010. Identifikasi Bakteri Asam Laktat yang diisolasi dari Biskuit Blondo Yang Berpotensi Menghambat Bakteri Patogen. Padang: Universitas Andalas

Hidayat, Habibi. 2011. Karakterisasi Molekuler BAL Dengan Gen 16S rRNA Penghasil ENzim Protease Yang berpotensi sebagai Probiotik Dari Fermentasi Markisa Kuning di Sumatera Barat. Padang: Universitas Andalas

Mardiana, 2007. Uji Aktivitas Antibakteri Ekstrak Daun dan Biji Kecubung (Datura metel L) Terhadap Bakteri Escherichia coli dan Bacillus cereus. Bengkulu: UNIB

Overlando, Redho dkk. 2013. Fermentasi Buah Markisa (Passiflora) menjadi Asam Sitrat. Palembang: Universitas Sriwijaya

Surono, Ingrid S. 2004. Probiotik Susu Fermentasi Dan Kesehatan. Jakarta: PT. Tri Cipta Karya (TRICK) 